\title{
Survey of the Javan Gibbons (Hylobates moloch) in West and Central Java, Indonesia: Trends in Population Density
}

Entang Iskandar ${ }^{1^{*}}$, Walberto Sinarga ${ }^{1}$, Septiantina Riendriasari ${ }^{2}$, Rahmuddin $^{3}$, Kuswandono Tedjosiswojo $^{4}$ and Randall C Kyes $^{1,5}$

${ }^{1}$ Primate Research Center, Bogor Agricultural University, Bogor, Indonesia

${ }^{2}$ Research and Development Center of Non-Timber Forest Products Technology, West Lombok, Indonesia

3/slamic High School, Natal, North Sumatera, Indonesia

${ }^{4}$ Gunung Ciremai National Park, Directorate General of Natural Resources and Ecosystem Conservation,

Ministry of Environment and Forestry, Republic of Indonesia

${ }^{5}$ Department of Psychology and Global Health, Center for Global Field Study, and Washington National Primate Research Center, University of Washington, Seattle, USA

*Corresponding author: Entang Iskandar, Primate Research Center, Bogor Agricultural University, Bogor, Indonesia, Tel: (62) 251-8313637; E-mail: eniskandar@yahoo.com

Received date: October 03, 2017; Accepted date: April 26, 2018; Published date: May 03, 2018

Copyright: ( 2018 Iskandar E, et al. This is an open-access article distributed under the terms of the Creative Commons Attribution License, which permits unrestricted use, distribution, and reproduction in any medium, provided the original author and source are credited.

\begin{abstract}
The Javan gibbon is endemic to Java with remaining populations restricted to a few protected areas. This species is currently endangered with habitat loss considered the most serious threat to the long-term viability. Current population estimates (e.g. density, abundance) for the Javan gibbon are limited and variable. As such, there is a critical need to provide thorough monitoring of the existing population. This survey was conducted at five protected areas located in the provinces of West and Central Java from April 2008 to August 2009. The survey areas included Gunung Gede Pangrango National Park, Gunung Simpang Nature Reserve, Gunung Papandayan Protection Forest, Leuweung Sancang Nature Reserve, and Gunung Slamet Protection Forest. The goal of the project was to generate population density estimates for the species that can contribute to the assessment of population trends and conservation priorities in these protected areas. All surveys involved the use of line-transect sampling along transects of 1 to $3.5 \mathrm{~km}$ in length with repeated multiple times to generate reliable density estimates. Average group and individual densities were highest at Gunung Gede Pangrango NP (2.5 groups $/ \mathrm{km}^{2}$ and 5.7 individuals $\left./ \mathrm{km}^{2}\right)$ and lowest at Leuweung Sancang NR (1.1 groups $/ \mathrm{km}^{2}$ and 2.4 individuals $\left./ \mathrm{km}^{2}\right)$. A coordinated approach to the conservation of the existing Javan gibbon population is a high priority and should include long-term population monitoring combined with the assessment of habitat suitability.
\end{abstract}

Keywords: Indonesia; Javan gibbon; Endangered; Endemic; Population density; Protected areas; Conservation

\section{Introduction}

The Javan gibbon (Hylobates moloch) is endemic to the island of Java, Indonesia with a distribution now limited to provinces in the western (Banten and West Java) and central (Central Java) parts of the island. It is currently categorized as Endangered by the IUCN Red List [1]. Javan gibbons live in family groups consisting of two parents and their offspring. They are almost entirely arboreal and dependent on primary or suitable secondary forest [2].

Some of the earliest research on Javan gibbons, now almost 40 years ago by Kappeler in 1978 [2], documented serious concern for the longterm survival of the species due to habitat destruction, hunting and capture. Anthropogenic activity continues to have a progressive and dramatic impact on existing populations with habitat loss and fragmentation presenting a significant threat to the species' survival $[3,4]$. Some estimates suggest that Java has lost more than $90 \%$ of its original forest cover [5] and that the Javan gibbon has lost approximately $96-98 \%$ of its habitat [6,7]. Considering the dates of these estimates, the current loss may be even greater.
As is the case with many primate species in the wild, the existing data on Javan gibbon population parameters (e.g. population density, abundance) are limited and show considerable variation [8]. In 1994, a Population and Habitat Viability Analysis (PHVA) workshop estimated the Javan gibbon population in the wild to be only 400 individuals, distributed among 21 forest fragments [9]. In 2000, the Javan gibbon was listed as one of 25 most endangered primate species in the world [10]. More recent estimates suggest a population size closer to 4,000-4,500 individuals [8,11]. Given the on-going anthropogenic pressure from habitat loss and disturbance, coupled with limited information on long-term population trends in key protected Javan gibbon habitats, there is a critical need to establish regular population monitoring to ensure the long-term viability of the Javan gibbons in the wild.

The purpose of current study was to conduct a broad survey of the Javan gibbons at five protected forests on Java that are known to support existing populations of the species. All five forest areas also have been surveyed in previous studies. Four sites were located in West Java: Gunung Gede Pangrango National Park, Gunung Simpang Nature Reserve, Gunung Papandayan Protection Forest, and Leuweung Sancang Nature Reserve, and one site in Central Java: Gunung Slamet Protection Forest. Our goal was to generate population density estimates for this endangered species that can help support 
Citation: Iskandar E, Sinarga W, Riendriasari S, Rahmuddin, Tedjosiswojo K, et al. (2018) Survey of the Javan Gibbons (Hylobates moloch) in West and Central Java, Indonesia: Trends in Population Density. Biol Syst Open Access 7: 184. doi:10.4172/2329-6577.1000184

Page 2 of 9

subsequent population monitoring and contribute to the assessment of population trends and conservation priorities in these protected areas.

\section{Methods}

\section{Study sites}

Surveys were conducted at five protected areas on Java. Each protected area was known to have an existing population of Javan gibbons that had been assessed by other researchers at some point during the past 25 years.

Gunung Gede Pangrango National Park (GGPNP): GGPNP is located in West Java (S06 $\left.44^{\prime} / \mathrm{E}^{106^{\circ}} 41^{\prime}\right)$, administratively in the regencies of Bogor, Sukabumi and Cianjur. The park encompasses a total area of about $228.5 \mathrm{~km}^{2}$ and varies in elevation from about $740 \mathrm{~m}$ to $3,019 \mathrm{~m}$ asl. GGPNP is a mountainous tropical rain forest consisting of three types of ecosystems, sub-montane, montane and sub-alpine. The park is home for more than 110 species of mammals including several primate species: the Endangered Javan gibbon (Hylobates moloch), the vulnerable ebony leaf monkey (Trachypithecus auratus), the Endangered grizzled leaf monkey (Presbytis comata), the longtailed macaque (Macaca fascicularis) and the Critically Endangered Javan slow loris (Nycticebus javanicus).

Gunung Simpang Nature Reserve (GSNR): GSNR is located in West Java $\left(\mathrm{S} 07^{\circ} 17^{\prime} / \mathrm{E} 107^{\circ} 21^{\prime}\right)$ and covers an area of $150 \mathrm{~km}^{2}$ of highland forest with the elevations ranging between $800 \mathrm{~m}$ to $1,823 \mathrm{~m}$ asl. GSNR is in the regencies of Bandung and Cianjur and is inhibited by four species of primates including the Javan gibbon, the ebony leaf monkey, the grizzled leaf monkey and the long-tailed macaque.

Gunung Papandayan Protection Forest (GPPF): GPPF is located in West Java (S07 $\left.21^{\prime} / E 107^{\circ} 41^{\prime}\right)$ in the regencies of Garut and Bandung. GPPF is $68.1 \mathrm{~km}^{2}$ in size consisting of hilly and mountainous terrain ranging in elevation between $865 \mathrm{~m}$ to $2,200 \mathrm{~m}$ asl. During the study period, the protected forest boundary was closed to access due to risks associated with an active volcano. Therefore, we conducted our survey outside the perimeter of GPPF, but still within the forest zone immediately adjacent to the protected area. There are three species of primates found in GPPF: the Javan gibbon, the grizzled leaf monkey, and the Javan slow loris [12].
Leuweung Sancang Nature Reserve (LSNR): LSNR is located near the south coast of West Java $\left(\mathrm{S}^{\circ} 7^{\circ} 43^{\prime} / \mathrm{E} 107^{\circ} 53^{\prime}\right)$ and encompasses an area of approximately $21.6 \mathrm{~km}^{2}$. LSNR consists of lowland rain forest and varies in elevation from $0 \mathrm{~m}$ to $175 \mathrm{~m}$ asl. Four species of primates inhibit the reserve including, the Javan gibbon, the ebony leaf monkey, the grizzled leaf monkey, and the long-tailed macaque.

Gunung Slamet Protection Forest (GSPF): GSPF is located in Central Java $\left(\mathrm{S} 07^{\circ} 17^{\prime} / \mathrm{E} 109^{\circ} 11^{\prime}\right)$ with has a total area about $200 \mathrm{~km}^{2}$. The GSPF contains the second highest mountain in Java and varies in elevation from $600 \mathrm{~m}$ to $3,000 \mathrm{~m}$ asl [13]. There are four species for primates found in GSPF: the Javan gibbon, the grizzled leaf monkey, the ebony leaf monkey and the long-tailed macaque [4].

\section{Data collection}

Surveys were conducted from April 2008 through August 2009 using the line-transect sampling method outlined by the National Research Council [14]. Line-transect sampling is an efficient method for the assessment of primate populations [15] and has been employed for survey work where rapid estimates of populations in inaccessible terrain or in widely different geographic areas are required [16]. It is also used for detailed studies within a limited geographic area, including monitoring of temporal changes in density [17], for comparison of habitats within the same general area [18], and for estimation of populations in areas where other methods (markrecapture, complete counts, home range or territory mapping, etc.) are not feasible $[19,20]$.

Sampling was conducted along two to three transects at each protected area. Transects ranged in length from 1.0 to $3.5 \mathrm{~km}$ (depends on survey locations and severity of topography) and were located in representative habitat types at each site (i.e., has tree plantations, and provided food sources).Transects were sampled once a day in a single direction during early morning (beginning at $\sim 6: 00 \mathrm{am}$ ) and repeated multiple times to generate reliable density estimates. Sampling was postponed during periods of rain or high wind. Transect details for each protected area is presented in Table 1.

\begin{tabular}{|c|c|c|c|c|}
\hline Protected Area & Transect Length & Coordinates & Elevation $(m)$ & $\begin{array}{l}\text { No. of Survey Samples } \\
\text { (Repeats) }\end{array}$ \\
\hline \multicolumn{5}{|c|}{ GGPNP (survey dates: 18 July-14 August 2009) } \\
\hline \multirow[b]{2}{*}{ Trans-1 } & & S06 $46^{\prime} 33.9^{\prime \prime} / \mathrm{E} 106^{\circ} 51^{\prime} 14.5^{\prime \prime}$ & \multirow[b]{2}{*}{$1551-1784$} & \multirow[b]{2}{*}{9} \\
\hline & 3 & S06 $46^{\prime} 41.0^{\prime \prime} / \mathrm{E} 106^{\circ} 51^{\prime} 34.7^{\prime \prime}$ & & \\
\hline \multirow[b]{2}{*}{ Trans-2 } & & S06 $44^{\prime} 58.6^{\prime \prime} / \mathrm{E} 106^{\circ} 59^{\prime} 7.8^{\prime \prime}$ & \multirow[b]{2}{*}{$764-819$} & \multirow[b]{2}{*}{9} \\
\hline & 2.5 & $\mathrm{~S} 06^{\circ} 44^{\prime} 54.7^{\prime \prime} / \mathrm{E} 106^{\circ} 59^{\prime} 23.4^{\prime \prime}$ & & \\
\hline \multicolumn{5}{|c|}{ GSNR (survey dates: 23 April-29 May 2008) } \\
\hline \multirow[b]{2}{*}{ Trans-1 } & & $\mathrm{S} 07^{\circ} 17^{\prime} 53.5^{\prime \prime} / \mathrm{E} 107^{\circ} 22^{\prime} 01.8^{\prime \prime}$ & \multirow[b]{2}{*}{$1150-1210$} & \multirow[b]{2}{*}{16} \\
\hline & 3.5 & $\mathrm{~S} 07^{\circ} 18^{\prime} 51.3^{\prime \prime} / \mathrm{E} 107^{\circ} 22^{\prime} 27.8^{\prime \prime}$ & & \\
\hline \multirow[b]{2}{*}{ Trans-2 } & & $\mathrm{S} 07^{\circ} 17^{\prime} 32.2^{\prime \prime} / \mathrm{E} 107^{\circ} 22^{\prime} 12.5^{\prime \prime}$ & \multirow[b]{2}{*}{$1199-1384$} & \multirow[b]{2}{*}{14} \\
\hline & 3.2 & S07 $17^{\prime} 14.4^{\prime \prime} / \mathrm{E} 107^{\circ} 23^{\prime} 35.7^{\prime \prime}$ & & \\
\hline
\end{tabular}


Citation: Iskandar E, Sinarga W, Riendriasari S, Rahmuddin, Tedjosiswojo K, et al. (2018) Survey of the Javan Gibbons (Hylobates moloch) in West and Central Java, Indonesia: Trends in Population Density. Biol Syst Open Access 7: 184. doi:10.4172/2329-6577.1000184

Page 3 of 9

\begin{tabular}{|c|c|c|c|c|}
\hline \multirow[b]{2}{*}{ Trans-3 } & \multirow[b]{2}{*}{3.5} & $\mathrm{~S} 07^{\circ} 17^{\prime} 38.6^{\prime \prime} / \mathrm{E} 107^{\circ} 22^{\prime} 18.4^{\prime \prime}$ & \multirow[b]{2}{*}{ 1116-1075 } & \multirow[b]{2}{*}{16} \\
\hline & & S07 $18^{\prime} 30.8^{\prime \prime / E} 107^{\circ} 23^{\prime} 28.7^{\prime \prime}$ & & \\
\hline \multicolumn{5}{|c|}{ GPPF (survey dates: 4 November-15 December 2008) } \\
\hline \multirow[b]{2}{*}{ Trans-1 } & & $\mathrm{S} 07^{\circ} 21^{\prime} 56.9^{\prime \prime} / \mathrm{E} 107^{\circ} 41^{\prime} 09.5^{\prime \prime}$ & \multirow[b]{2}{*}{$1171-1193$} & \multirow[b]{2}{*}{15} \\
\hline & 3.5 & $\mathrm{~S} 07^{\circ} 21^{\prime} 53.4^{\prime \prime} / \mathrm{E} 107^{\circ} 40^{\prime} 59.0^{\prime \prime}$ & & \\
\hline \multirow[b]{2}{*}{ Trans-2 } & \multirow[b]{2}{*}{3} & $\mathrm{~S} 07^{\circ} 22^{\prime} 15.7^{\prime \prime} / \mathrm{E} 107^{\circ} 41^{\prime} 03.2^{\prime \prime}$ & \multirow[b]{2}{*}{ 1194-1056 } & \multirow[b]{2}{*}{9} \\
\hline & & $\mathrm{S} 07^{\circ} 22^{\prime} 46.7^{\prime \prime} / \mathrm{E} 107^{\circ} 41^{\prime} 30.9^{\prime \prime}$ & & \\
\hline \multirow[b]{2}{*}{ Trans-3 } & \multirow[b]{2}{*}{3} & S07 $22^{\prime} 29.1^{\prime \prime / E} 107^{\circ} 41^{\prime} 46.8^{\prime \prime}$ & \multirow[b]{2}{*}{$1177-1109$} & \multirow[b]{2}{*}{9} \\
\hline & & $\mathrm{S} 07^{\circ} 22^{\prime} 33.9^{\prime \prime} / \mathrm{E} 107^{\circ} 41^{\prime} 21.6^{\prime \prime}$ & & \\
\hline \multicolumn{5}{|c|}{ LSNR (survey dates: 26 June-3 August 2008) } \\
\hline \multirow[b]{2}{*}{ Trans-1 } & \multirow[b]{2}{*}{1} & $\mathrm{~S} 07^{\circ} 43^{\prime} 40.3^{\prime \prime} / \mathrm{E} 107^{\circ} 53^{\prime} 31.3^{\prime \prime}$ & \multirow[b]{2}{*}{$20-67$} & \multirow[b]{2}{*}{14} \\
\hline & & $\mathrm{S} 07^{\circ} 43^{\prime} 40.2^{\prime \prime} / \mathrm{E} 107^{\circ} 53^{\prime} 35.0^{\prime \prime}$ & & \\
\hline \multirow[b]{2}{*}{ Trans-2 } & \multirow[b]{2}{*}{2} & $\mathrm{~S} 07^{\circ} 43^{\prime} 42.3^{\prime \prime} / \mathrm{E} 107^{\circ} 53^{\prime} 35.1^{\prime \prime}$ & \multirow[b]{2}{*}{$47-96$} & \multirow[b]{2}{*}{10} \\
\hline & & $\mathrm{S} 07^{\circ} 43^{\prime} 32.4^{\prime \prime} / \mathrm{E} 107^{\circ} 53^{\prime} 29.7^{\prime \prime}$ & & \\
\hline \multirow[b]{2}{*}{ Trans-3 } & \multirow[b]{2}{*}{2.5} & $\mathrm{~S} 07^{\circ} 43^{\prime} 41.4^{\prime \prime} / \mathrm{E} 107^{\circ} 53^{\prime} 37.9^{\prime \prime}$ & \multirow[b]{2}{*}{$35-108$} & \multirow[b]{2}{*}{12} \\
\hline & & $\mathrm{S} 07^{\circ} 43^{\prime} 32.4^{\prime \prime / E} 107^{\circ} 53^{\prime} 43.6^{\prime \prime}$ & & \\
\hline \multicolumn{5}{|c|}{ GSPF (survey dates: 4-30 March 2009) } \\
\hline \multirow[b]{2}{*}{ Trans-1 } & \multirow[b]{2}{*}{3} & 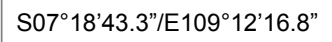 & \multirow[b]{2}{*}{$650-850$} & \multirow[b]{2}{*}{7} \\
\hline & & S07 $17^{\prime} 55.6^{\prime \prime} / \mathrm{E} 109^{\circ} 11^{\prime} 33.5^{\prime \prime}$ & & \\
\hline \multirow[b]{2}{*}{ Trans-2 } & \multirow[b]{2}{*}{3} & S07'18'43.4"/E109'12'40.0" & & \\
\hline & & S07'17'43.2"/E109'11'49.3" & $650-900$ & 7 \\
\hline
\end{tabular}

Table 1: Transect details for each protected area.

Following standard sampling procedures outlined by the National Research Council [14], two to three observers walked slowly and quietly along the transect making frequent stops to scan the area and listen for gibbons. When a group/individual was encountered (visually), the following information was recorded: time of sighting, location along the transect (via GPS coordinates), perpendicular distance from the transect to the first animal observed (via rangefinder) and number of animals observed (and age/sex class when possible). Groups/individuals encountered were observed for a maximum of $10 \mathrm{~min}$. Only data involving visual sightings of gibbon groups (two or more individuals) were used for analysis, thus allowing for highly conservative estimates of both group and individual density. Visual sightings of single animals were rare but were noted when observed.

To allow comparison of the data with those from earlier studies, density estimates were calculated following methods described by the National Research Council [14]. Additionally, density estimates also were calculated using the software program DISTANCE [21,22], a contemporary standard for analyzing line-transect data. As we have noted elsewhere [23], some researchers have raised concerns that
DISTANCE may overestimate densities of forest primate groups [24]. Nevertheless, the DISTANCE values were generated to provide baseline comparison for subsequent population surveys of Javan gibbons.

Our research adhered to the legal requirements and applicable laws of Indonesia and complied with the animal care protocol approved by the Institutional Animal Care and Use Committee at the University of Washington, and the American Society of Primatologists (ASP) Principles for the Ethical Treatment of Nonhuman Primates.

\section{Results}

Over the course of the 16 month study period, we conducted a total of 147 survey samples (representing $418.8 \mathrm{~km}$ ) along 13 transects distributed among the five protected areas (Table 1). Javan gibbons were encountered (visually) along all transects in the five protected areas. Based on recorded perpendicular sighting distances, no gibbons were observed visually beyond $50 \mathrm{~m}$ and thus for the purpose of density calculation [14], a strip width of $100 \mathrm{~m}$ was used. This is consistent with other studies that have reported a detection distance of 
Citation: Iskandar E, Sinarga W, Riendriasari S, Rahmuddin, Tedjosiswojo K, et al. (2018) Survey of the Javan Gibbons (Hylobates moloch) in West and Central Java, Indonesia: Trends in Population Density. Biol Syst Open Access 7: 184. doi:10.4172/2329-6577.1000184

Page 4 of 9

$50 \mathrm{~m}$, e.g. [25,26]. The maximum elevation where gibbons were sighted was $1,651 \mathrm{~m}$ asl, along transect \#1 in GGPNP; the lowest elevation of sighting was $59 \mathrm{~m}$ asl along transect \#1 in LSNR. The majority of encounters involved group sightings. Single animals were rarely encountered during the surveys and only at GSNR, GPPF and LSNR (on average 2.3 sightings per entire survey period at each protected area (range 2-3). As noted above, these data were not included in the density calculations.

\begin{tabular}{|c|c|c|c|c|c|c|}
\hline Protected Area & Km Surveyed & $\mathrm{Km}^{2}$ Surveyed & Group Encounters & Groups/km² & Mean Group Size & Individuals/km² \\
\hline \multicolumn{7}{|l|}{ GGPNP } \\
\hline Trans-1 & 27 & 2.7 & 6 & 2.2 & 2.5 & 5.5 \\
\hline Trans-2 & 22.5 & 2.25 & 6 & 2.7 & 2.2 & 5.9 \\
\hline Mean & & & & 2.5 & 2.4 & 5.7 \\
\hline \multicolumn{7}{|l|}{ GSNR } \\
\hline Trans-1 & 56 & 5.6 & 10 & 1.8 & 2.1 & 3.8 \\
\hline Trans-2 & 44.8 & 4.48 & 7 & 1.6 & 2.1 & 3.4 \\
\hline Trans-3 & 56 & 5.6 & 9 & 1.6 & 2.4 & 3.8 \\
\hline Mean & & & & 1.7 & 2.2 & 3.7 \\
\hline \multicolumn{7}{|l|}{ GPPF } \\
\hline Trans-1 & 52.5 & 5.25 & 6 & 1.1 & 2.3 & 3 \\
\hline Trans-2 & 27 & 2.7 & 3 & 1.1 & 2.3 & 2.5 \\
\hline Trans-3 & 27 & 2.7 & 3 & 1.1 & 2.7 & 2.9 \\
\hline Mean & & & & 1.1 & 2.4 & 2.6 \\
\hline \multicolumn{7}{|l|}{ LSNR } \\
\hline Trans- 1 & 14 & 1.4 & 2 & 1.4 & 2 & 2.8 \\
\hline Trans-2 & 20 & 2 & 2 & 1 & 2.5 & 2.5 \\
\hline Trans-3 & 30 & 3 & 3 & 1 & 2 & 2 \\
\hline Mean & & & & 1.1 & 2.2 & 2.4 \\
\hline \multicolumn{7}{|l|}{ GSPF } \\
\hline Trans-1 & 21 & 2.1 & 3 & 1.4 & 2.3 & 3.2 \\
\hline Trans-2 & 21 & 2.1 & 2 & 0.9 & 2.5 & 2.3 \\
\hline Mean & & & & 1.2 & 2.4 & 2.8 \\
\hline \multicolumn{7}{|c|}{ Note: Respective mean group and individual density estimates from DISTANCE (ver. 6.0, release 2 ) are presented below } \\
\hline \multicolumn{7}{|c|}{$\begin{array}{l}\text { Values represented include- DE: density estimate/km²; CI: } 95 \% \text { Confidence Intervals of the Density Estimates; \% CV: Coefficient of Variation of the Density Estima } \\
\text { expressed as a Percentage; ESW: Effective Strip Width }\end{array}$} \\
\hline
\end{tabular}

Table 2a: Density estimates of Javon Gibbons in west and central java.

\begin{tabular}{|l|l|l|l|l|}
\hline Protected Area & DE & CI & \%CV & ESW \\
\hline GGPNP & 2.5 & $1.2-5.3$ & 38.2 & \\
\hline Groups & 5.8 & $2.7-12.5$ & 38.7 & $49.0 \mathrm{~m}$ \\
\hline Individuals & & & \\
\hline GSNR
\end{tabular}


Citation: Iskandar E, Sinarga W, Riendriasari S, Rahmuddin, Tedjosiswojo K, et al. (2018) Survey of the Javan Gibbons (Hylobates moloch) in West and Central Java, Indonesia: Trends in Population Density. Biol Syst Open Access 7: 184. doi:10.4172/2329-6577.1000184

Page 5 of 9

\begin{tabular}{|c|c|c|c|c|}
\hline Groups & 1.8 & $1.1-3.1$ & 26.5 & \\
\hline Individuals & 3.9 & $2.3-6.7$ & 26.7 & $47.0 \mathrm{~m}$ \\
\hline \multicolumn{5}{|l|}{ GPPF } \\
\hline Groups & 1.4 & $0.6-3.1$ & 40.6 & \multirow[b]{2}{*}{$41 \mathrm{~m}$} \\
\hline Individuals & 3.3 & $1.5-7.5$ & 41.1 & \\
\hline \multicolumn{5}{|l|}{ LSNR } \\
\hline Groups & 1.2 & $0.5-2.9$ & 46 & \multirow[b]{2}{*}{$47.0 \mathrm{~m}$} \\
\hline Individuals & 2.5 & $1.0-6.2$ & 46.4 & \\
\hline \multicolumn{5}{|l|}{ GSPF } \\
\hline Groups & 1.4 & $0.5-4.2$ & 53.3 & $42.0 \mathrm{~m}$ \\
\hline Individulas & 3.4 & $1.1-10.2$ & 54.3 & \\
\hline
\end{tabular}

Table 2b: Density estimates of Javon Gibbons in west and central java.

Density estimates, while relatively consistent within each protected area, did vary across areas (Tables $2 \mathrm{a}$ and $2 \mathrm{~b}$ ). The two western-most protected areas GGPNP followed by GSNR had the highest mean density estimates at 2.5 groups $/ \mathrm{km}^{2}$ and 5.7 individuals $/ \mathrm{km}^{2}$; and 1.7 groups $/ \mathrm{km}^{2}$ and 3.7 individuals $/ \mathrm{km}^{2}$, respectively. The three remaining areas (GPPF, LSNR, and GSPF) had similar density estimates with average group densities ranging between 1.1-1.2 groups $/ \mathrm{km}^{2}$ and mean population densities between $2.4-2.8$ individuals $/ \mathrm{km}^{2}$. It is important to note that we have not attempted to estimate population size for the five protected areas due to the fact that we were not able to survey a greater number of locations within each area.

Mean group size was relatively consistent both within and across protected areas and ranged between 2.0-2.7 individuals per group (individual group sizes ranged between $2-5$ individuals). Observed group composition (for all group encounters at all study sites) consisted of at least two adults and often with one infant/juvenile offspring. Adult pairs with two offspring also were observed at GSNR and GGPNP (where the greatest number of two-offspring groups was observed). Finally, there was one observed group encounter consisting of an adult pair with three offspring, also at GGPNP-thus representing the area with largest observed group size.

During the surveys, three other primate species, the ebony leaf monkey, the grizzled leaf monkey, and the long-tailed macaque, were encountered at each of the protected areas, except GSPF, where just the grizzled leaf monkey was observed. On a few occasions, Javan gibbons were seen using the same trees for food with the grizzled leaf monkey (approximately $30 \mathrm{~m}$ apart) thus suggesting a sympatric association.

\section{Discussion}

This study provides updated population density estimates of the Javan gibbon at five protected areas in West and Central Java. Gibbons were observed in all five of the protected areas thus supporting the need for continued monitoring and conservation at these sites. All of the gibbon encounters occurred in hill/lower montane forest at elevations between $59 \mathrm{~m}-1,651 \mathrm{~m}$ asl. These finding are consistent with more recent reports that suggest the majority of Javan gibbons currently inhabit forest areas between $500 \mathrm{~m}-1,500 \mathrm{~m}[8,27,28]$.

Among the five protected areas, the highest density estimates for the Javan gibbon were found at GGPNP, also the location with the largest protected forest area. Conversely, the areas with the lowest estimated densities were those smallest in size, GPPF and LSNR. The explanation for the variation in density, however, is likely far more complex than simply habitat size. For example, food source abundance, habitat suitability, and anthropogenic habitat disturbance (loss, fragmentation), hunting/pet trade are among the variables known to influence gibbon population parameters [29]. Some have noted a negative correlation between level of habitat disturbance and Javan gibbon density [8]. While all protected areas experience some level of habitat disturbance, particularly along the boundaries, gibbon populations living in small protected areas may be impacted more severely given that they have fewer options (suitable habitat) to avoid the disturbance. Protected areas of larger size, however, are better able withstand habitat encroachment and can offer sufficient suitable habitat for Javan gibbons thus allowing them to avoid the disturbance and maintain higher densities.

There are two additional protected areas, Ujung Kulon National Park and Gunung Halimun-Salak National Park, considerably larger in size than the five areas in this study, that extend the general observation of higher gibbon densities in areas of larger size. Both are considered to represent the best protected habitats supporting Javan gibbon populations at present. Ujung Kulon National Park is located in Banten Province (formerly part of West Java) and is approximately $1,133 \mathrm{~km}^{2}$ in size. A previous survey by our team conducted from November-December $2000[30,31]$ indicated density estimates for the Javan gibbon at 2.8 groups $/ \mathrm{km}^{2}$ and 9.2 individuals $/ \mathrm{km}^{2}$ (based on a survey at one location in the park using two transects). Other researchers have reported similar density estimates: 2.6 groups $/ \mathrm{km}^{2}$ and 8.9 individuals $/ \mathrm{km}^{2}$ [32]; 2.3 groups $/ \mathrm{km}^{2}$ and 10.7 individuals $/ \mathrm{km}^{2}$ [33]; and 3.3 groups $/ \mathrm{km}^{2}$ and 8.9 individuals $/ \mathrm{km}^{2}$ [34]. Gunung Halimun-Salak National Park is located in West Java and is approximately $786 \mathrm{~km}^{2}$ in size. Previous surveys by our team during 
Citation: Iskandar E, Sinarga W, Riendriasari S, Rahmuddin, Tedjosiswojo K, et al. (2018) Survey of the Javan Gibbons (Hylobates moloch) in West and Central Java, Indonesia: Trends in Population Density. Biol Syst Open Access 7: 184. doi:10.4172/2329-6577.1000184

Page 7 of 9

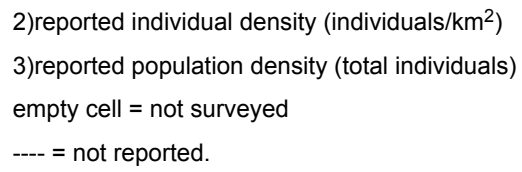

GGPNP (Gunung Gede Pangrango National Park); GSNR (Gunung Simpang Nature Reserve); GPPF (Gunung Papandayan Protection Forest); LSNR (Leuweung Sancang Nature Reserve); GSPF (Gunung Slamet Protection Forest).

Table 3: Comparision of Javan Gibbon population estimates at five protected areas during past 25 years.

We believe the value of our data is based in part on the fact that the surveys were conducted by the same group of researchers using the same sampling method at multiple sites over a relatively short period of time. This allows for a more accurate comparison of density estimates among areas and establishment of baseline measures for subsequent monitoring and evaluation. As noted earlier, we have not attempted to estimate population size for the five protected areas. This is due to the fact that we were not able to survey a greater number of locations within each area (due to constraints on time and funding). As such, we acknowledge that our ability to generalize or extrapolate our findings to an entire protected area is limited [46]. It is also important to note that population estimates that are generated even when multiple locations are sampled may still be at risk of overestimation.

As habitat disturbance/loss remains an on-going problem at all protected areas, a critical factor that must be included in the population size equation is habitat suitability. This point is well illustrated in a recent study that assessed the habitat suitability of GGPNP [47]. Applying a principal component analysis and general linear model to assess multiple habitat variables, they determined that only $55.8 \%$ of the park's total area $(22,851 \mathrm{ha})$ represented high $(3,918$ ha) to moderate $(8,823$ ha) suitability for Javan gibbons. Clearly, estimates of current population size at GGPNP would vary dramatically if one were to simply apply the density estimates to the park's total available habitat versus the actual suitable habitat. Therefore, as part of a broad gibbon conservation management strategy, it is essential that systematic assessment of each protected area be conducted on a periodic basis to help generate measures of current habitat suitability, allowing for more precise estimates of existing population.

A coordinated approach to the management and conservation of the javan gibbon population on Java is long overdue and should be a high priority. A program involving regular, long-term population monitoring is essential to help track population parameters, evaluate potential anthropogenic impact, and evaluate the effectiveness of various conservation and management strategies [23,48]. We recommend a monitoring program that will include the five protected areas surveyed in this study, plus Ujung Kulon National Park and Gunung Halimun-Salak National Park, and other locations with existing Javan Gibbon populations such as Dieng Mountains. These areas that are the main focus in population monitoring are conservation areas considering majority of the surviving Javan gibbons are in protected areas. The areas are still providing tree plantation for the gibbons as the species are almost entirely arboreal and dependent on primary or suitable secondary forest [2]. However, population survey of the Javan gibbon outside conservation areas is also needed to identify location status and how they can survive outside conservation areas. Therefore, we can determine necessary conservation actions, such as establishing corridors among unprotected areas to the closest conservation area, and assigning unprotected area to be protected area. Regular population surveys conducted by well-trained research teams using the same uniform survey methods, combined with on-going assessment of habitat suitability, represent essential components of a broad-based management plan needed to ensure the long-term viability of the Javan gibbon population.

\section{Conclusion}

The Average group and individual densities were highest at Gunung Gede Pangrango NP (2.5 groups $/ \mathrm{km}^{2}$ and 5.7 individuals $/ \mathrm{km}^{2}$ ) and lowest at Leuweung Sancang NR (1.1 groups $/ \mathrm{km}^{2}$ and 2.4 individuals $/ \mathrm{km}^{2}$ ). A coordinated approach to the conservation of the existing Javan gibbon population is a high priority and should include long-term population monitoring combined with the assessment of habitat suitability.

\section{Acknowledgement}

We wish to convey our deepest gratitude to the heads of the National Parks and Nature Reserves, as well as the Perum Perhutani for their permission and assistance with this study. We also are grateful to Keni Sultan, MSi, the rangers, porters and local people who assisted with logistics in the field. Special thanks to Dr. Pensri Kyes, Erik McArthur and Azhari Purbatrapsila, Shut for technical assistance with the preparation of this article. The project was supported in part by the National Geographic Society Conservation Trust (Grant Number C 141-08 to E.I.), a Conservation Grant from the Primate Society of Great Britain (to E.I.) and the Office of Research Infrastructure Programs (ORIP) of the National Institutes of Health through Grant Number P51OD010425. This research adhered to the legal requirements and applicable laws of Indonesia and complied with the animal care protocol approved by the Institutional Animal Care and Use Committee at the University of Washington, and the American Society of Primatologists (ASP) Principles for the Ethical Treatment of Nonhuman Primates.

\section{References}

1. Andayani N, Brockelman W, Geissmann T, Nijman V, Supriatna J (2008) Hylobates moloch. In: The IUCN Red List of Threatened Species. Version 2017-1.

2. Kappeler M (1984) The gibbon in Java. In: H Preuschoft, DJ Chivers, W Brockelman, N Creel (Eds.), The lesser apes: Evolutionary and behavioral biology. Edinburgh University Press, Edinburgh.

3. Estrada A, Garber PA, Rylands AB, Roos C, Fernandez-Duque E, et al. (2017) Impending extinction crisis of the world's primates: Why primates matter. Sci Adv 3: e1600946. 
Citation: Iskandar E, Sinarga W, Riendriasari S, Rahmuddin, Tedjosiswojo K, et al. (2018) Survey of the Javan Gibbons (Hylobates moloch) in West and Central Java, Indonesia: Trends in Population Density. Biol Syst Open Access 7: 184. doi:10.4172/2329-6577.1000184

Page 8 of 9

4. Nijman V (2013) One hundred years of solitude: Effects of long-term forest fragmentation on the primate community of Java, Indonesia. In: LK Marsh, CA Chapman (eds) Primates in fragments: Complexity and resilience. Springer, New York.

5. Whitten AJ, Soeriaatmaja RE, Afiff SA (1996) The ecology of Java and Bali. Periplus, Hong Kong.

6. MacKinnon J (1984) The distribution and status of gibbons in Indonesia In: H Preuschoft, DJ Chivers, WY Brockelman, N Creel (Eds.), The lesser apes: Evolutionary and behavioural biology. Edinburgh University Press, Edinburgh, pp: 16-18.

7. MacKinnon K (1987) Conservation status of primates in Malaysia, with special reference to Indonesia. Primate Conservation 8: 175-183.

8. Kim S, Lappan S, Choe JC (2011) Diet and ranging behavior of the endangered Javan gibbons (Hylobates moloch) in a submontane tropical rainforest. Am J Primatol 73: 270-280.

9. Supriatna J, Tilson R, Gurmaya J, Manansang J, Wardoyo W, et al. (1994) Javan gibbon and Javan langur: Population and habitat viability analysis report. IUCN/SSC Conservation Breeding Specialist Group. Apple Valley, Minnesota.

10. Mittermeier RA, Padua CV, Rylands AB, Eudey AA, Butynski TM, et al. (2005) Primates in peril: The world's 25 most endangered primates 2004-2006. Primate Conservation 20: 1-28

11. Nijman V (2004) Conservation of the Javan gibbon Hylobates moloch: Population estimates, local extinctions and conservation priorities. The Raffles Bulletin of Zoology 52: 271-280.

12. Rode-Margono EJ, Nekaris KAI (2014) Impact of climate and moonlight on a venomous mammal, the Javan slow loris (Nycticebus javanicus Geoffroy, 1812). Contributions to Zoology 83: 217-225.

13. Nijman V (2013) Distribution and ecology of the most tropical of the high-elevation montane colobines: The ebony langur on Java. In: NB Grow, S Gursky-Doyen, A Krzton (eds) High altitude primates. Springer, New York, pp: 115-132.

14. National Research Council (1981) Techniques for the study of primate population ecology. National Academy Press, Washington DC.

15. Ferrari SF, Chagas RRD, Souza-Alves JP (2010) Line transect surveying of arboreal monkeys: Problems and group size of spread in highly fragmented landscape. Am J Primatol 72: 1100-1107.

16. Nijman V, van Balen S (1998) A faunal survey of the Dieng mountains, Central Java, Indonesia: Distribution and conservation of endemic primate taxa. Oryx 32: 145-156.

17. Glanz WE (1982) The terrestrial mammal fauna of Barro Colorado island: Census and long-term changes. In: EG Leigh, AS Rand, DM Windsor (eds) The ecology of a tropical forest. Smithsonian Institute Press, Washington.

18. Johns AD, Skorupa JP (1987) Responses of rain-forest primates to habitat disturbance: A review. Int J Primatol 8: 157-191.

19. Green KM (1978) Primate censuring in Northern Colombia: A comparison of two techniques. Primates 19: 537-550.

20. Blouch RA (1997) Distribution and abundance of orangutan (Pongo pygmaeus) and other primates in the Lanjak Entimau wildlife reserve, Sarawak, Malaysia. Trop Biodivers 3: 259-274.

21. Buckland ST, Anderson DR, Burnham KP, Laake JL, Borchers DL, et al (2001) Introduction to distance sampling. Oxford University Press, Oxford.

22. Thomas L, Buckland ST, Rexstad EA, Laake JL, Strindberg S, et al. (2010) Distance software: Design and analysis of distance sampling surveys for estimating population size. J Appl Ecol 47: 5-14.

23. Kyes RC, Iskandar E, Paputungan U, Onibala J, Laatung S, et al. (2013) Long term population survey of the Sulawesi black macaques (Macaca nigra) at Tangkoko Nature Reserve, North Sulawesi, Indonesia. Am J Primatol 75: 88-94.

24. Lwanga JS, Struhsaker TT, Struhsaker PJ, Butynski TM, Mitani JC (2011) Primate population dynamics over 32.9 years at Ngogo, Kibale National Prak, Uganda. Am J Primatol 73: 997-1011.
25. Sugardjito J, Southwick CH, Supriatna J, Kohlhaas A, Baker S, et al. (1989) Population survey of macaques in northern Sulawesi. Am J Primatol 18: 285-301.

26. Rosenbaum B, O’Brien TG, Kinnaird M, Supriatna J (1998) Population densities of Sulawesi crested black macaques (Macaca nigra) on Bacan and Sulawesi, Indonesia: Effects of habitat disturbance and hunting. Am J Primatol 44: 89-106.

27. Nijman V (2006) In situ and ex situ status of the Javan gibbon and the role of zoos in conservation of the species. Contributions of Zoology 75: 161-168.

28. Supriatna J, Mootnick A, Andayani N (2010) Javan gibbon (Hylobates moloch) population and conservation. In: S Gursky, J Supriatna (eds) Indonesian Primates. Springer, New York.

29. Supriatna J (2006) Conservation programs for the endangered Javan gibbon (Hylobates moloch). Primate Conservation 21: 155-162.

30. Iskandar E (2001) Population survey of the Javan gibbon (Hylobates moloch) at the Ujung Kulon National Park, West Java, Indonesia. ASP Bull 25: 9.

31. Iskandar E, Kyes RC, Alikodra HS, Manjoer SS, Bismark M (2008) Comparison of the Javan gibbon (Hylobates moloch) population at Gunung Halimun-Salak and Ujung Kulon National Park, Indonesia. Primate Eye 96: 203.

32. Gurmaya KJ, Adiputra IMW, Saryatiman AB, Danardono SM, Sibuea TTH (1995) Primate survey, population and ecology: Gunung Honje range Ujung Kulon National Park. Departemen Kehutanan and New Zealand Ministry of Foreign Affairs and Trade. Jakarta.

33. Rinaldi D (1999) Food preferences and habitat utilization of Java gibbon (Hylobates moloch Audebert) in Ujung Kulon National Park, West Java, Indonesia. MSc Thesis, Universitat Georg-August, Gottingen, Germany.

34. Fuentes A (2000) Hylobatid communities: Changing views on pair bonding and social organization in hominoids. Yearbook of Physical Anthropology 43: 33-60.

35. Iskandar E, Sinaga W, Kyes RC (2006) Population survey of the Javan gibbon (Hylobates moloch) at Gunung Halimun National Park, West Java, Indonesia. Am J Primatol 68: 108-109.

36. Iskandar E (2007) Habitat and population of the Javan gibbon (Hylobates moloch) at Gunung Halimun-Salak Nationa Park, West Java. PhD dissertation, Bogor Agricultural University, Bogor.

37. Kool KM (1992) The status of endangered primates in Gunung Halimun reserve, Indonesia. Oryx 26: 29-33.

38. Sugarjito J, Sinaga MH, Yoneda M (1997) Survey of the distribution and density of primates in Gn. Halimun National Park, West Jawa, Indonesia. In: The inventory of national resources in Gunung Halimun National Park, LIPI, JICA, PHPA, Bogor 2: 56-62.

39. Geissmann T, Nijman V (2006) Calling in wild silvery gibbons (Hylobates moloch) in Java Indonesia: Behavior, phylogeny and conservation. Am J Primatol 68: 1-19.

40. Malone NM (2007) The Socioecology of the critically endangered Javan gibbon (Hylobates moloch): Assessing the impact of anthropogenic disturbance on primate social systems. PhD. Dissertation, University of Oregon, Oregon.

41. Asquith NM (1995) Javan gibbon conservation: Why habitat protection is crucial. Trop Biodivers 3: 63-65.

42. Djanubudiman G, Arisona J, Iqbal M, Wibisono F, Mulcahyo G, et al. (2004) Current distribution and conservation priorities for the Javan gibbon (Hylobates moloch). Report to Great Ape Conservation Fund, US Fish and Wildlife Service, Washington DC, Indonesian Foundation for Advance of Biological Sciences and Center for Biodiversity and Conservation Studies of University of Indonesia, Depok.

43. Iskandar F, Mardiastuti A, Iskandar E, Kyes RC (2009) Javan gibbon population (Hylobates moloch) at Gunung Gede Pangrango National Park, West Java. Indonesian J Primatol 6: 14-18.

44. Setiawan A, Nugroho TS, Wibisono Y, Ikawati V, Sugardjito J (2012) Population density and distribution of Javan gibbon (Hylobates moloch) in Central Java, Indonesia. Biodiversitas 13: 23-27. 
Citation: Iskandar E, Sinarga W, Riendriasari S, Rahmuddin, Tedjosiswojo K, et al. (2018) Survey of the Javan Gibbons (Hylobates moloch) in West and Central Java, Indonesia: Trends in Population Density. Biol Syst Open Access 7: 184. doi:10.4172/2329-6577.1000184

Page 9 of 9

45. Reisland AR, Lambert JE (2016) Sympatric apes in sacred forests: Shared space and habitat use by humans and endangered Javan gibbons (Hylobates moloch). PLoS One 11: e0146891.

46. Buckland ST, Plumptre AJ, Thomas L, Rexstad EA (2010) Design and analysis of line transect surveys for primates. Int J Primatol 31: 833-847.

47. Suheri H, Nakagoshi N, Suwandana E (2014) Habitat suitability and assessment of corridors setup for Javan gibbon conservation: A case study of Gunung Gede Pangrango National Park, Indonesia. Asian J Conserv Biol 3: 19-27.

48. Plumptre AJ, Cox D (2006) Counting primates for conservation: Primate surveys in Uganda. Primates 47: 65-73.

49. Wahyuni S, Nasution EK (2016) Studi Populasi Owa Jawa (Hylobates moloch) di Lereng Gunung Slamet Jawa Tengah. Biosfera 33: 48-51. 